\title{
Use of Vitamin C in Delayed Tooth Replantation
}

\author{
Sônia Regina PANZARINI \\ Antônio César PERRI DE CARVALHO \\ Wilson Roberto POI \\ Celso Koogi SONODA \\ Department of Surgery and Integrated Clinics, Faculty of Dentistry of Araçatuba, São Paulo State University (UNESP), \\ Araçatuba, SP, Brazil
}

\begin{abstract}
This study evaluated microscopically the effects of root surface treatment with three different solutions in delayed rat teeth replantation. Central incisors from 30 rats (Rattus norvegicus, albinus Wistar) were extracted and left on a bench for $6 \mathrm{~h}$. The pulps were extirpated and root canals were irrigated with $1 \%$ sodium hypochlorite. After endodontic treatment, the root surfaces of all teeth were submitted to a 10-min treatment with $1 \%$ sodium hypochlorite, changed every $5 \mathrm{~min}$. The teeth were then rinsed with saline for $10 \mathrm{~min}$ and assigned to 3 groups with ten specimens each. Groups I, II and III were treated, respectively, with $2 \%$ acidulated-phosphate sodium fluoride, vitamin C solution and effervescent vitamin C $\left(2 \mathrm{~g}\right.$, Redoxon $\left.{ }^{\circledR}\right)$. After root surface treatment, the teeth were filled with calcium hydroxide and replanted. The animals were sacrificed after 10 and 60 days. Group I (fluoride) presented the largest areas of replacement resorption and ankylosis. Comparing both vitamin C groups, Group III (effervescent vitamin C) yielded better results, showing more areas of ankylosis and replacement resorption than areas of inflammatory resorption.
\end{abstract}

Key Words: tooth replantation, ascorbic acid, sodium hypochlorite, sodium fluoride.

\section{INTRODUCTION}

Studies investigating delayed tooth replantation are aimed at answering the many persistent questions regarding the treatment of accidental avulsion (1). One important issue of success in these cases is related to root surface treatment (2-4). The search for the best clinical protocol for cases of delayed tooth replantation has been a recurrent subject among many researchers (2-9). Although several root surface treatment procedures have been suggested, none of them provided definite results.

The use of sodium hypochlorite for the removal of periodontal ligament remnants, as well as the use of acids for root surface conditioning has been investigated $(7,8)$. Among the acidic solutions, the acidulatedphosphate sodium fluoride has yielded the most favorable results $(7,8,10)$ and is recommended by the American Association of Endodontists (AAE) guidelines for delayed tooth replantation (11).

Vitamin $C$ is an acidic molecule and has properties capable of influencing tissue repair, which might play an important role in delayed tooth replantation $(12,13)$ but has not yet been investigated with such purpose. Therefore, this study evaluated microscopically, in delayed rat teeth replantation, the effects of root surface treatment with $1 \%$ sodium hypochlorite, followed by the application of three different solutions: $2 \%$ acidulated-phosphate sodium fluoride, vitamin $\mathrm{C}$ and effervescent vitamin $\mathrm{C}$.

\section{MATERIAL AND METHODS}

Thirty male rats (Rattus norvegicus, albinus Wistar) weighing about 250-300 $\mathrm{g}$ had their right central incisors extracted and left on a bench for $6 \mathrm{~h}$.

Afterwards, the dental papilla and the enamel organ of the teeth were sectioned, the pulps were extirpated through a retrograde via and the root canals were irrigated with $1 \%$ sodium hypochlorite. After root canal preparation, the root surfaces of all teeth were submitted to a 10-min treatment with $1 \%$ sodium hypochlorite, changed every $5 \mathrm{~min}$. The teeth were rinsed with saline for $10 \mathrm{~min}$ and assigned to 3 groups with ten specimens 
in each. Groups I, II and III were treated, respectively, with $2 \%$ acidulated-phosphate sodium fluoride (Apothicário Farmácia de Manipulação, Araçatuba, SP, Brasil) for 10 min, vitamin C (Apothicário Farmácia de Manipulação) for $10 \mathrm{~min}$ and effervescent vitamin C (Redoxon ${ }^{\circledR} 2$ g, Roche Produtos Químicos e Farmacêuticos S.A., Rio de Janeiro, RJ, Brasil) for 10 $\min$.

Teeth were filled with a calcium hydroxide paste (Calcium Hydroxid Für Analyse, Criedel, De Rainag Seelge, Hannover, Germany) and replanted after removal of blood clot and alveolar irrigation with saline. All animals received 20,000 IU of penicillin G benzathine (Eurofarma Laboratório, São Paulo, SP, Brasil) in a single dose (ip).

The rats were sacrificed 10 days ( $n=5 /$ group) and 60 days ( $n=5 /$ group) post-surgery and the samples were sent to histological processing. They were embedded in paraffin and 6- $\mu$ m-thick sections were obtained and stained with hematoxylin-eosin (H\&E) for histologic and histometric analyses.

\section{Histometric Analysis Method}

Several methods have been described in the literature for histometric analysis and the advances in informatics, especially regarding image analysis softwares, have prompted the development of newer approaches. However, there is not a standard method for tooth replantation studies, particularly those using longitudinal histologic sections. On account of this and based on the authors' background knowledge (14), the histometric analysis method proposed in this study uses digital images with a panoramic view of the longitudinal histologic sections, which enables the measurement of the events related to tissue repair.

Ten sections were analyzed from 10 different slides of each experimental group, at the 10th and 60th postoperative days. The chosen sections were digitalized using an optical scanner (HP 4C/T; HewlettPackard Development Company, Palo Alto, CA, USA) and saved using an image management software (ImageLab 2000; Laboratório de Informática Dedicado à Odontologia - LIDO - USP, São Paulo, SP, Brasil). Once the digital images were obtained, a scale was adjusted in micrometers and the corresponding area of the root was selected, cut and quantified, so that the total area of dentin in the root could be obtained. The numerical data included the total measurement of the area, and the percentages relating to each region were saved as a different file. The areas of inflammatory and replacement resorptions were selected, quantified and data were saved as described above. The analysis of the digital images was compared to the analysis of the same slides seen under light microscopy for an accurate identification and selection of areas of resorption. Data file was then saved in Excel 1.4 software (Microsoft Corporation, Redmond, WA, USA) for statistical analysis.

Root perimeter measurements allowed for quantification of the areas of ankylosis. The total root surface perimeter and the perimeter of the areas of ankylosis were measured.

ANOVA and Tukey's test were used for statistical analysis.

\section{RESULTS}

10 Days

In group I (acidulated-phosphate sodium fluoride), the gingival epithelium was located close to the cementum, below the cementoenamel junction. Little amount of periodontal ligament (PDL) was present at the three alveolar thirds, and the cementum and dentin were intact in the majority of the samples (Fig. 1). The alveolar bone wall, at the cervical and middle thirds, showed areas of bone apposition, which caused the narrowing of the PDL space. There was new trabecular bone formation at the bottom of the socket.

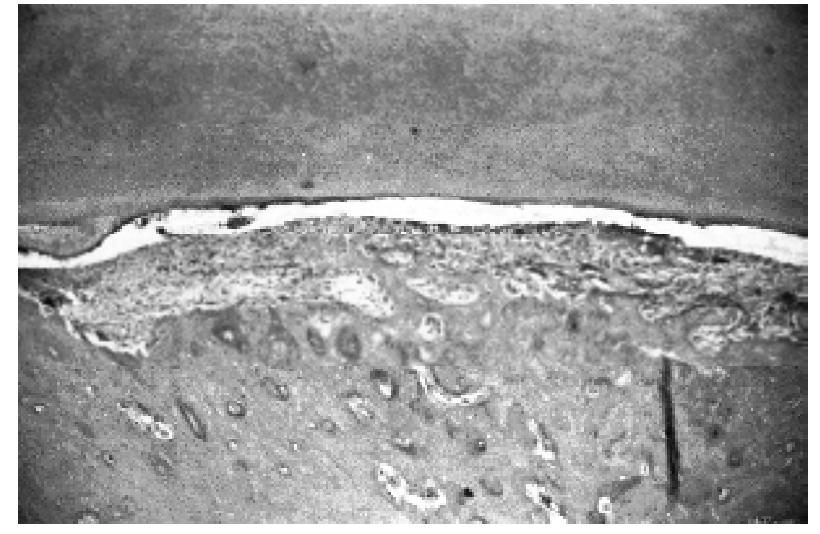

Figure 1. Group I (10 days): Little amount of periodontal ligament and integrity of dentin and cementum. H\&E (original magnification X63). 
In group II (vitamin C), the gingival epithelium showed, in some cases, intense proliferation towards the bottom of the socket. Fibroblasts disposed parallel to cementum were observed in the PDL at the middle and apical thirds. There were small areas of inflammatory resorption in both cementum and dentin at the cervical third (Fig. 2). The alveolar bone wall showed areas of bone apposition, which caused the narrowing of the PDL space. New trabecular bone formation was observed at the bottom of the socket.

In group III (effervescent vitamin C), the gingival epithelium was located close to the cementum, below the cementoenamel junction. Numerous fibroblasts disposed parallel to the cementum were noted at the three thirds of the PDL. Cementum and dentin showed areas of active and non-active surface resorp-

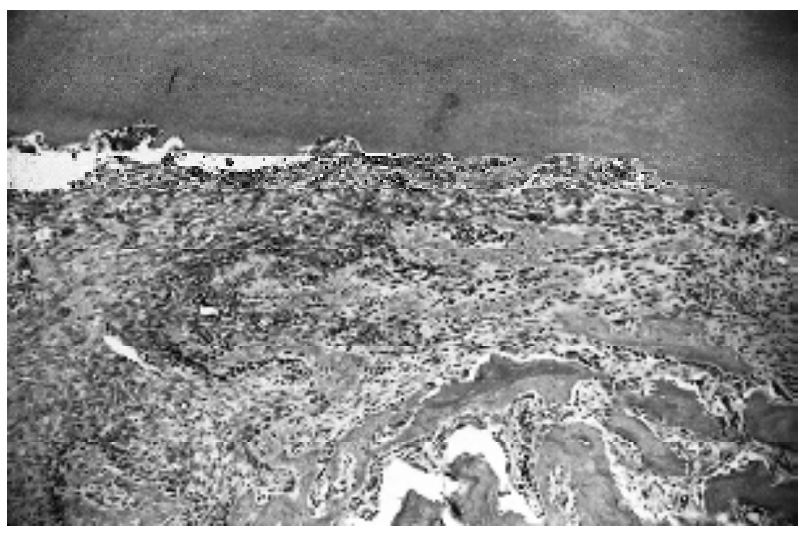

Figure 2. Group II (10 days): Area of inflammatory resorption at the cervical third. H\&E (original magnification X63).

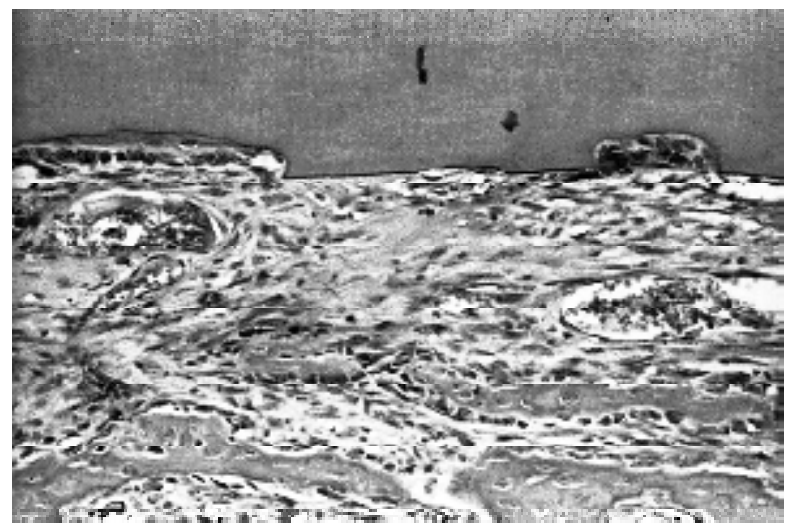

Figure 3. Group III (10 days): Fibroblasts disposed parallel to the root and areas of surface resorption. $\mathrm{H} \& \mathrm{E}$ (original magnification $\mathrm{X} 160)$. tion along the cervical and middle thirds (Fig. 3). The alveolar bone wall, at the cervical and middle thirds, showed areas of bone apposition, which caused the narrowing of the PDL space. Thin trabecular bone was noted at the bottom of the socket without bone differentiation.

\section{Days}

In group I (acidulated-phosphate sodium fluoride), the gingival epithelium was located adjacent to the cementum, below the cementoenamel junction. There were a moderate number of PDL fibers at the cervical third. At the middle third, except for one sample, the periodontal ligament was replaced by newly formed bone, which almost filled the PDL space (Fig. $4)$. There were resorption areas in both cementum and dentin. Except for the apical third, the alveolar bone wall showed areas of bone apposition, which almost filled the PDL space in many places and reached dentin. There was new trabecular bone formation at the bottom of the socket, close to the alveolar bone wall.

In group II (vitamin C), the gingival epithelium was located adjacent to the cementum, below the cementoenamel junction. In some cases, little amount of PDL was still evident, with a small number of fibroblasts and blood vessels. In two specimens, cementum and dentin showed areas of active resorption with multinucleated cells at the cervical and middle thirds (Fig. 5). The alveolar bone wall showed intensive bone apposition, which in most cases, filled the PDL space and reached the cementum and/or dentin surface. At the

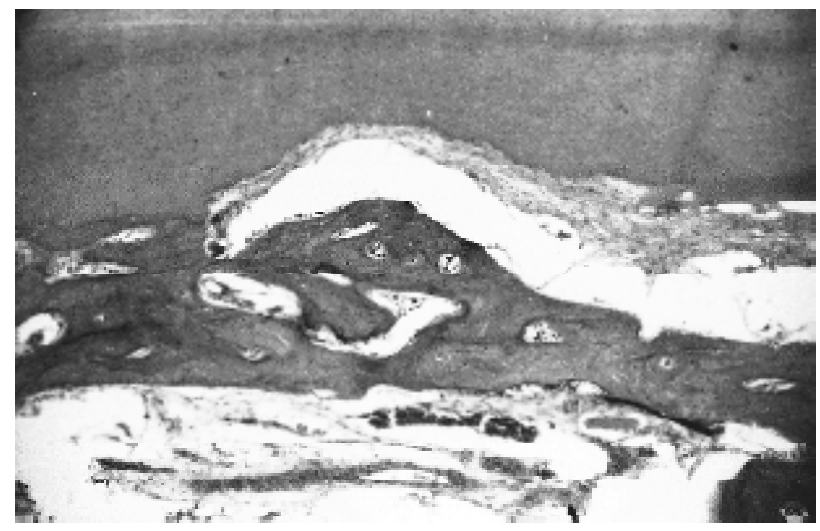

Figure 4. Group I (60 days): Little amount of remnant periodontal ligament, most of which was replaced by bone. H\&E (original magnification X63). 
bottom of the socket, newly formed trabecular bone was observed, mainly close to the alveolar bone wall.

In group III (effervescent vitamin $\mathrm{C}$ ), the gingival epithelium was located adjacent to the cementum, below the cementoenamel junction. The PDL was still present in some specimens at the cervical third and, in one of the specimens, it was replaced by newly formed bone, which reached the dentin in some areas. In few

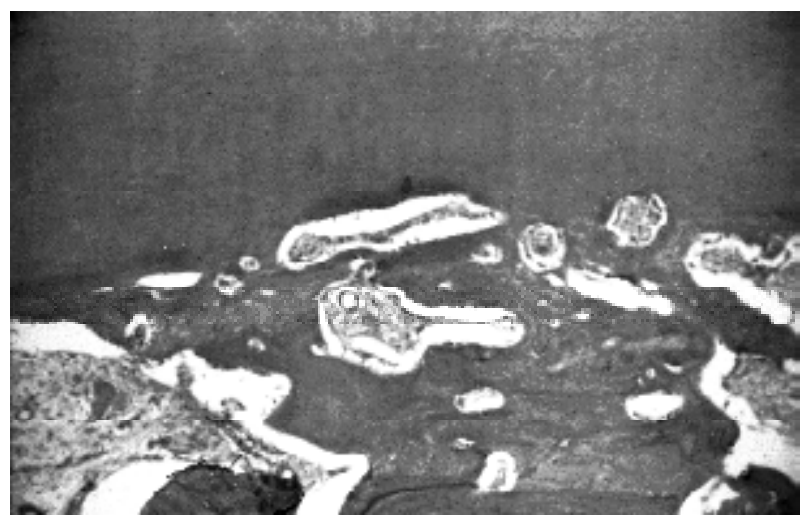

Figure 5. Group II (60 days): Areas of replacement resorption. H\&E (original magnification X63).

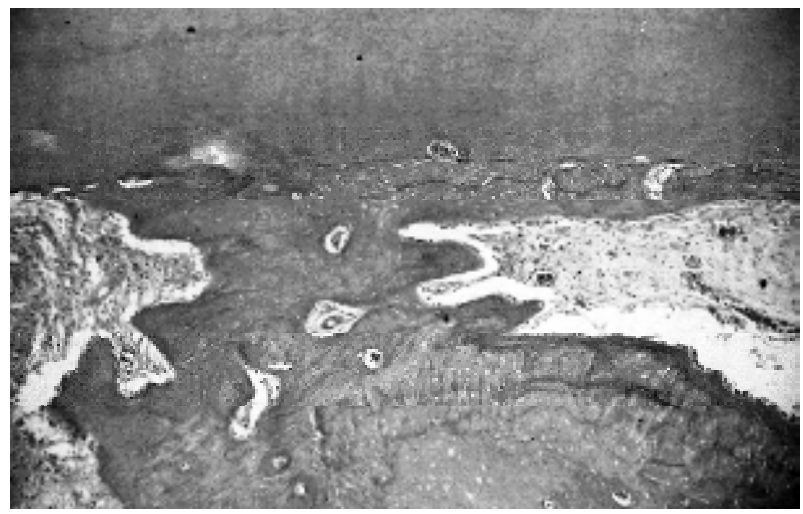

Figure 6. Group III (60 days): Little amount of cementum in contact with bone. H\&E (original magnification X63).

Table 1. Means of resorption areas.

\begin{tabular}{lcccc}
\hline Group & $\begin{array}{c}\text { Replacement } \\
\text { Resorption (\%) }\end{array}$ & $\begin{array}{c}\text { Inflammatory } \\
\text { Resorption (\%) }\end{array}$ & $\begin{array}{c}\text { 2X Inflammatory Resorption } \\
\text { + Replacement Resorption (\%) }\end{array}$ & $\mathrm{p}<0.01^{*}$ \\
\hline Fluoride & 1.59 & 0 & 1.59 & $\mathrm{a}$ \\
Vitamin C & 1.37 & 1.41 & 4.19 & $\mathrm{~b}$ \\
Redoxon & 1.45 & 0.17 & 2.12 & $\mathrm{a}$ \\
\hline
\end{tabular}

*Different letters indicate statistical significance. specimens, little amount of cementum was observed adjacent to the newly formed bone at the middle and cervical thirds (Fig. 6). The alveolar bone wall showed intense bone apposition, filling the PDL space and reaching the cementum and/or dentin in the majority of the specimens. At the bottom of the socket, neoformed trabecular bone was observed, mainly close to the alveolar bone wall.

The means of resorption areas obtained in the histometric analysis are given in Table 1.

Data analyzed statistically were obtained from light microscopy findings at 60 days because, in all experimental groups, both replacement and inflammatory resorptions were not seen within the first 10 days.

Because it is considered an aggravation in tooth replantation, inflammatory resorption was used as a differentiation factor. Inflammatory resorption means were multiplied by 2 and subsequently added to the replacement resorption means, as suggested by Dezan Júnior (15).

Analysis of variance detected significant difference among the root surface treatments evaluated. Tukey's test showed that $2 \%$ acidulated-phosphate sodium fluoride yielded the most favorable results, followed by Redoxon and vitamin $\mathrm{C}(\mathrm{p}=0.01)$. Fluoride and Redoxon presented similar results $(\mathrm{p}>0.05)$.

\section{DISCUSSION}

The high incidence of delayed tooth replantation (1) and the storage medium for avulsed teeth were the reasons for our choice of working with dried teeth after a long extra-alveolar period. Due to the impairment to pulp vitality, root canals were prepared and filled with a calcium hydroxide paste, which reportedly neutralizes the toxins, facilitates the repair and has antibacterial properties $(5,16)$.

The presence of little inflammatory resorption in Groups II and III and the absence of inflammatory resorption in Group I may be attributed to the effects of calcium hydroxide in infection control, mainly via root canal. However, the ability of calcium hydroxide to spread through dentin tubules may also contribute to some effects on root surface.

The administration of an 
antibioticotherapy associated with endodontic treatment was probably responsible for the low inflammatory root resorption rate observed in all groups. An antibiotic regimen is indicated to control the factors resulting from contamination not only on root surface, but also inside the dental alveolus, particularly after a long extra-alveolar period (6).

The periodontal ligament condition at the moment of the replantation is a variable that may directly interfere with the outcomes of this procedure. Therefore, in case of necrosis, the PDL must be removed to minimize the risk of external root resorption, which is the main cause of loss of replanted teeth (2-4).

Based on the principle that the chemical removal of the periodontal ligament preserves the cementum layer, which seems to be more resistant to resorption than dentin, $1 \%$ sodium hypochlorite was utilized for elimination of PDL remnants $(7,8,17)$. The 10 -day results clearly showed that the cementum layer was preserved, with only few areas of surface resorption. The $1 \%$ sodium hypochlorite solution is reportedly less irritant, more stable and effective in the removal of the necrotic periodontal ligament. Furthermore, it is a material routinely found in dental offices $(8,17)$. The findings of this study suggested that the concentration and time did not interfere with root resorption, as these results were compared to those of previously reported investigations using similar methodology.

At the 10-day evaluation, most of specimens presented connective tissue between the root and the bone tissue, which suggested a tissue reaction to the chemical solution, as described by Sonoda et al. (8) while investigating different concentrations of sodium hypochlorite for root surface treatment. These authors (8) observed that an increase in this chemical reaction is directly related to an increase in the solution concentration, which in turn leads to tooth loss.

Acidic solutions have been used on root surface to facilitate the reattachment of connective fibers and the acidulated fluoride solutions have shown the most favorable results, mainly when the periodontal ligament is degenerated or had been removed $(9,10)$.

The choice for $2 \%$ acidulated-phosphate sodium fluoride as a control was based on the AAE treatment guidelines for delayed replantation of avulsed teeth. The literature has supported that this protocol leads to the best results $(9,10)$. Accordingly, the findings of the 60 -day evaluation showed more areas of ankylosis and replacement resorption for Group I (treatment of root surface with $2 \%$ acidulated-phosphate sodium fluoride) than for the vitamin $\mathrm{C}$ groups.

The ascorbic acid investigated in this study is a widely spread vitamin in all body tissues. It is essential for the hydroxylation of proline and lysine, which are very important during the synthesis of collagen $(12,13,18)$. Its absorption depends on tissue concentration. If available at an appropriate concentration, the ascorbic acid is responsible for maintaining the efficacy and the phagocytosis activity of leucocytes (19).

Considering all these properties and the lack of reports with similar methodology, vitamin $\mathrm{C}$ was tested under two different conditions: a solution prepared at a pharmacy at pH 2 and a commercially available effervescent solution (Redoxon $2 \mathrm{~g}$ - one pastille diluted in $100 \mathrm{~mL}$ of distilled water) at $\mathrm{pH}$. Because of the instability of the solution made in a pharmacy, the effervescent vitamin $\mathrm{C}$ was tested for the development of a protocol that could be easily used by clinicians and could allow for a longer storage period. This might have accounted for the less favorable results of group II, which had more inflammatory resorption areas compared to group III.

Vitamin C also plays a role in osteogenesis by the activation of alkaline phosphatase and increase in the functional activity of osteoblasts (20). This could explain the areas of replacement resorption and ankylosis observed in the specimens of group III at the 60-day evaluation. In addition, the antimicrobial effect of vitamin C could be responsible for the small number of inflammatory resorption areas observed in Group III (19), which yielded better results between the vitamin C groups, and presented statistically similar results to those of group I.

Based on the results of this study and the vitamin $\mathrm{C}$ properties, i.e., antimicrobial activity, induction of osteogenesis and synthesis of collagen, which could be of particular interest for tooth replantation, it is feasible to state that some advantages may possibly be taken from treating root surface with vitamin $\mathrm{C}$ before tooth replantation. Further research with adequate methodology should be carried out to investigate this possibility.

\section{RESUMO}

O objetivo deste trabalho foi avaliar microscopicamente, em reimplantes tardios de dentes de rato, os efeitos do tratamento da 
superfície radicular com diferentes soluções. Foram utilizados 30 ratos Rattus norvegicus albinos da linhagem Wistar que tiveram seus incisivos centrais extraídos e deixados sobre a bancada por $6 \mathrm{~h}$. As polpas foram extirpadas e os canais irrigados com solução de hipoclorito de sódio a $1 \%$. Após o preparo endodôntico, a superfície radicular de cada dente foi tratada com solução de hipoclorito de sódio a $1 \%$ por 10 min (trocada a cada $5 \mathrm{~min}$ ) seguida de soro fisiológico por $10 \mathrm{~min}$, e os dentes foram divididos em três grupos com 10 espécimes em cada um. Nos Grupos I, II e III, respectivamente, a superfície radicular foi tratada com fluoreto de sódio fosfato acidulado a $2 \%$, vitamina C e vitamina $\mathrm{C}$ efervescente $\left(2 \mathrm{~g}\right.$, Redoxon $\left.{ }^{\circledR}\right)$. Após obturação com pasta de hidróxido de cálcio os dentes foram reimplantados e os animais foram sacrificados aos 10 e 60 dias. O Grupo I apresentou maiores áreas de reabsorção por substituição e anquilose. Comparando as formas de vitamina $\mathrm{C}$ utilizadas, a efervescente (Grupo III) foi a que apresentou resultados mais favoráveis com mais áreas de anquilose e reabsorção por substituição que áreas de reabsorção inflamatória.

\section{REFERENCES}

1. Kemp WB, Mourino AP. Accidental extraction and replantation of an immature permanent tooth. J Endod 1977;3:240-241.

2. Andreasen JO. Relationship between cell damage in the periodontal ligament after replantation and subsequent development of root resorption: a time-related study in monkeys. Acta Odont Scand 1981;39:15-25.

3. Lindskog S, Pierce AM, Blomlof L, Hammarström L. The role of the necrotic periodontal membrane in cementum resorption and ankylosis. Endod Dent Traumatol 1985; 1:96-101.

4. Hammarström L, Blomöf L, Lindskog S. Dynamics of dentoalveolar ankylosis and associated root resorption. Endod Dent Traumatol 1989;5:163-175.

5. Hammarström L, Bolmlöf L, Feiglin, B, Lindskog SF. Effect of calcium hydroxide treatment on periodontal repair and root resorption. Endod Dent Traumatol 1986;2:184-189.

6. Sae-Lim, V, Wang CY, Trope M. Effect of systemic tetracycline and amoxicillin on inflammatory root resorption of replanted dogs' teeth. Endod Dent Traumatol 1998;14:216-220.

7. Sonoda CK. Reimplante dental mediato após o tratamento da superfície radicular com solução de hipoclorito de sódio a $2 \%$ e solução de fluoreto de sódio a $2 \%$, fosfato acidulado $\mathrm{pH} 5,5$ : estudo histomorfométrico em cães. [Doctoral thesis]. Araçatuba: Faculdade de Odontologia de Araçatuba, Universidade Estadual Paulista; 1997. 80 p.

8. Sonoda CK, Poi WR, Okamoto T, Toyota E, Takeda RH. Reimplante imediato de dentes após o tratamento da raiz com solução de hipoclorito de sódio a 1\%, 2,5\%, 5\% e $10 \%$. Rev Bras Odontol 2000;57:293-296.

9. Bjorvatn K, Massler M. Effect of fluorides on root resorption in replanted rat molars. Acta Odont Scand 1971;29:17-29.

10. Shulman LB, Gedalia I, Feingold RM. Fluoride concentration in root surfaces and alveolar bone of fluoride immersed incisors three weeks after replantation. J Dent Res 1973;52:1314-1316.

11. American Association of Endodontists. Recommended guidelines for the treatment of avulsed tooth. Chicago; 1994.

12. Guiland JC, Lequeu B, Oliveira EG. As vitaminas: do nutriente ao medicamento. São Paulo: Editora Santos; 1995

13. Bates CJ. Bioavailability of vitamin C. Eur J Clin Nutr 1997;51(suppl):1528-533

14. Poi, WR, Carvalho PSP, Panzarini SR, Dezan Júnior E, Souza G, Trevisan CL. Efeito da pasta de metronidazol, lidocaína e ascorbosilane $\mathrm{C}$ sobre o processo de reparo em alvéolos dentais infectados de ratos. Rev Bras Cir Implantodont 2000;7:22-27.

15. Dezan Júnior E. Retratamento endodôntico: avaliação do selamento marginal em função da presença de resíduo de material obturador e do emprego de solvente. [Master's thesis]. Rio de Janeiro: Faculdade de Odontologia, Universidade Federal do Rio de Janeiro; $1994.66 \mathrm{p}$.

16. Estrela C, Pesce HF. Chemical analysis of the liberation of calcium and hydroxyl ions from calcium tissue in the dog - Part I. Braz Dent J 1996;7:41-46.

17. Moorer WR, Wesselink PR. Factors promoting the tissue dissolving capability of sodium hypochlorite. Int Endod J 1982;15:187196.

18. Wilson CWM. Clinical pharmacological aspects of ascorbic acid Ann Ny Acad Sci 1975;258:355-376.

19. Goldschmidt MC. Reduced bactericidal activity in neutrophils from scorbutic animals and the effect of ascorbic acid on these target bacteria in vivo and in vitro. Am J Clin Nutr 1991;54:1214S-1220S.

20. Suguimoto T, Nakada M, Fukase M, Imai Y, Kinoshita Y, Fujita $T$. Effects of ascorbic acid on alkaline phosfatase activity and hormone responsiveness in the osteoblastic osteosarcoma cell line UMR-106. Calcif Tissue Int 1986;39:171-174.

Accepted September 14, 2003 